\title{
Application times, sources and doses of nitrogen on wheat cultivars under no till in the Cerrado region
}

\author{
Épocas de aplicação, fontes e doses de nitrogênio em cultivares de trigo sob plantio direto na \\ região do cerrado
}

\author{
Marcelo Carvalho Minhoto Teixeira Filho ${ }^{\mathrm{I}}$ Salatiér BuzettiI ${ }^{\mathrm{II}}$ Marcelo Andreotti ${ }^{\mathrm{II}}$ \\ Orivaldo Arf ${ }^{\text {III }}$ Marco Eustáquio de Sá ${ }^{\text {II }}$
}

\begin{abstract}
Proper management of nitrogen fertilization and using cultivars with high productive potential are essential to obtain high wheat yield. Thus, the objective of the present study was to assess the effects of different $N$ doses and sources, one with a nitrification inhibitor, applied at sowing or as side dressing, on the production components and yield of two wheat cultivars irrigated, under no till, cultivated in a region of low altitude Cerrado (Selvíria - MS). A randomized block design was used in a $5 \times 3 \times 2 \times 2$ factorial arrangement, that is, five nitrogen doses $\left(0,50,100,150\right.$ and $\left.200 \mathrm{~kg} \mathrm{ha}^{-1}\right)$, three nitrogen sources (ammonium sulfonitrate with nitrification inhibitor (Entec $\left.{ }^{\circledR}\right)$, ammonium sulfate and urea) and two nitrogen application times (at sowing or side dressing) on two wheat cultivars ('E 22' and ' $E$ 42') with three replications. There was no difference for grain yield between the wheat cultivars and among the nitrogen sources. The application of nitrogen totally at sowing is feasible as well as the traditional application at sowing and side dressing. The nitrogen doses increased the leaf $N$ content of the ' $E 22$ ' cultivar, resulting in a reduction in the hectolitric mass of the ' $E 42$ ' cultivar and increased grain yield of the ' $E 22$ ' and ' $E 42$ ' wheat yield cultivars, respectively, up to doses of 126 and $122 \mathrm{~kg} \mathrm{ha}^{-1} \mathrm{~N}$, regardless of the application time and the nitrogen source.
\end{abstract}

Key words: Triticum aestivum L., anticipating nitrogen fertilization, spray irrigation, winter cereals, grain yield.

\section{RESUMO}

O manejo adequado da adubação nitrogenada e a utilização de cultivares de alto potencial produtivo são essenciais para obtenção de altas produtividades de trigo. Sendo assim, o objetivo deste trabalho foi avaliar os efeitos de diferentes doses e fontes de $N$, sendo uma com inibidor de nitrificação, aplicadas no sulco de semeadura ou em cobertura, nos componentes de produção e na produtividade de duas cultivares de trigo irrigado, sob plantio direto, cultivado numa região de cerrado de baixa altitude (Selvíria - MS). O delineamento estatístico foi o de blocos ao acaso, em um esquema fatorial $5 \times 3 \times 2 \times 2$, ou seja, cinco doses de $N(0,50$, 100,150 e $200 \mathrm{~kg} \mathrm{ha}^{-1}$ ), três fontes de $N$ (Entec ${ }^{\circledR}$, sulfato de amônio e uréia) e duas épocas de aplicação de $N$ (na semeadura, ao lado das linhas ou em cobertura), em duas cultivares de trigo ('E 22' e 'E 42'), com 3 repetições. Não houve diferença para produtividade de grãos das cultivares de trigo e entre as fontes de N. A aplicação do nitrogênio totalmente em semeadura é viável, assim como a aplicação tradicional em semeadura e cobertura. $O$ incremento das doses de nitrogênio aumenta o teor de $N$ foliar da cultivar ' $E$ 22', proporciona redução da massa hectolítrica da cultivar ' $E$ 42' $e$ aumenta a produtividade de grãos das cultivares de trigo ' $E$ 22 ' e 'E 42', respectivamente, até as doses de 126 e $122 \mathrm{~kg} \mathrm{ha}^{-1}$ de $N$, independente da época de aplicação e da fonte de $N$.

Palavras-chave: Triticum aestivum L., antecipação da adubação nitrogenada, irrigação por aspersão, cereais de inverno, produtividade de grãos.

\section{INTRODUCTION}

The Brazilian Cerrado region has huge potential for expansion of the wheat crop with the perspective of providing, in the midterm, self-

'Programa de Pós-graduação em Sistemas de Produção, Universidade Estadual Paulista (UNESP), 56, 15385-000, Campus de Ilha Solteira, SP, Brasil. E-mail: mcmtf@yahoo.com.br. Autor para correspondência.

"Departamento de Fitossanidade, Engenharia Rural e Solos, UNESP, Campus de Ilha Solteira, SP, Brasil.

IIIDepartamento de Fitotecnia, Tecnologia de Alimentos e Sócio Economia, UNESP, Campus de Ilha Solteira, SP, Brasil. 
sufficiency in national production. According to ZAGONEL et al. (2002), the final crop yield is defined in function of cultivar used, the quantity of chemical agricultural and the management techniques used. The increasing use of cultivars with high productive potential has implied in more frequent use of nitrogenized fertilization, that has been shown to be important in defining grain yield.

Nitrogen is the most difficult nutrient to manage in soils of tropical and subtropical regions because of the many reactions to which it is subjected and its high instability in the soil (ERNANI, 2003). Small doses limit yield and high doses can lead to lodging, thus making harvesting difficult and resulting in a fall in yield. Furthermore, it can damage the environment because of nitrate lixiviation to underground water sheets and bring losses to the producer with the unnecessary expense of buying nitrogen fertilizer. Therefore, nitrogenized fertilization requires careful management regarding both the doses applied and the application period.

The $\mathrm{N}$ application period is currently one of the most dynamic aspects in nitrogen fertilization management of grasses in the no till system with grass succession because in the first years of adopting the system there may be an initial $\mathrm{N}$ shortage, resulting from the immobilization resulting from the microbial decomposition of residues of the preceding crop. Thus in some cases, anticipating nitrogenized fertilization, in relation to the conventional recommendations or even compared to the crop sowing, can be more efficient in increasing productivity of annual grain crops (KLUTHCOUSKI et al., 2006). ROS et al. (2003) tested different nitrogenized fertilization methods in no till and assessed the $\mathrm{N}$ availability and observed that total nitrogen application at sowing or at side dressing did not differ in the wheat grain yield. However, more studies are needed for the wheat crop in regions with a dry winter and controlled irrigation.

In this context the study of different $\mathrm{N}$ sources is also fundamental, because these fertilizers perform differently when applied to the soil, especially for $\mathrm{N}$ losses. Urea is the nitrogenized fertilizer most used in Brazil because of its comparative advantages in terms of cost, ease manufacturing and final cost for the producer. Urea presents a serious limitation, from the agronomic point of view, when applied on the soil surface because of the chances of losses through $\mathrm{NH}_{3}$ volatilization. Ammonium sulfate does not suffer ammonia $\left(\mathrm{N}-\mathrm{NH}_{3}\right)$ volatilization when the $\mathrm{pH}$ is lower than 7. However, the efficiency of these fertilizers is reduced basically by nitrate lixiviation. With the objective of increasing the efficiency of nitrogenized fertilizers, the ammonium nitrate fertilizer, ammonium sulfonitrate $\left(\right.$ Entec $\left.^{\circledR}\right)$ was recently released on the market that has $26 \% \mathrm{~N}$ total and $12 \%$ sulfur, mostly in the ammoniacal form (18.5\% ammoniacal and $7.5 \%$ in the nitric form). Entec $^{\circledR}$ contains DMPP molecules (3.4 dimethylpirazolphosphate) that act on nitrification inhibition (LOS FERTILIZANTES, 2006). Inhibition of the nitrification process is interesting because it maintains the $\mathrm{N}$ in the form of $\mathrm{NH}^{+}$that is available to the plants for longer and thus reduces the nitrogen losses from $\mathrm{NO}_{3}{ }^{-}$lixiviation.

Nevertheless, studies on the response of the production components and yield of wheat to nitrogen fertilization are insufficient and should be carried out under specific environmental conditions, such as the low altitude Cerrado region, where irrigation has to be used. Thus the objective of this study was to assess the effects of different nitrogen doses and sources, one of which was the nitrification inhibiter Entec $^{\circledR}$ applied totally at sowing or at side dressing, on the production components and yield of two irrigated wheat cultivars, under no till, cropped in the Cerrado of low altitude.

\section{MATERIAL AND METHODS}

The experiment was conducted in 2006, in an experimental area belonging to the Engineering Faculty-UNESP, located in Selvíria - MS, with geographic coordinates $51^{\circ} 22^{\prime}$ longitude West and $20^{\circ}$ 22 ' latitude South and $335 \mathrm{~m}$ altitude. The soil is classified as Dystrophic Red Latosol, clayey texture, according to the new denomination of the Brazilian soil classification system (EMBRAPA, 2006). It was originally occupied by Cerrado vegetation and cultivated with annual crops for more than 25 years. The climatic classification of the region according to Köppen is Aw, defined as wet tropical with a rainy season in the summer and a dry season in the winter. The mean annual temperature is $20.5^{\circ} \mathrm{C}$, the mean annual rainfall is $1370 \mathrm{~mm}$ and the relative air humidity is between 70 and $80 \%$.

The chemical characteristics of the soil of the experimental area at the depths from 0.0 to $0.20 \mathrm{~m}$ were determined before the experiment was set up, according to methodology proposed by RAIJ \& QUAGGIO (1983) and presented the following results: $22 \mathrm{mg} \mathrm{dm}^{-3} \mathrm{P}$ (resin); $22 \mathrm{mg} \mathrm{dm}^{-3} \mathrm{~S} ; 27 \mathrm{~g} \mathrm{dm}^{-3}$ de M.O.; $5.9 \mathrm{pH}\left(\mathrm{CaCl}_{2}\right) ; \mathrm{K}, \mathrm{Ca}, \mathrm{Mg}, \mathrm{H}+\mathrm{Al}=3.3 ; 47.0 ; 16.0$ and $28.0 \mathrm{mmol}_{\mathrm{c}} \mathrm{dm}^{-3}$, respectively, and $70 \%$ saturation by bases.

A randomized block design was used, in a $5 \times 3 \times 2 \times 2$ factorial arrangement, that is, five nitrogen 
concentrations $\left(0,50,100,150\right.$ and $\left.200 \mathrm{~kg} \mathrm{ha}^{-1}\right)$, three $\mathrm{N}$ sources (ammonium sulfonitrate with inhibitor of nitrification - Entec ${ }^{\circledast}$, ammonium sulfate and urea) and two $\mathrm{N}$ application times (at sowing or side dressing), on two wheat cultivars ('E 22' and 'E 42') with three replications. The plots were $5 \mathrm{~m}$ long with two rows spaced at $0.17 \mathrm{~m}$ and 80 seeds per meter, for the two growing seasons.

The treatments were installed in a location where the no till system had been implanted eight years ago. This area was previously used for corn cropping. The area was desiccated using glyphosate herbicide $\left(1500 \mathrm{~g} \mathrm{ha}^{-1}\right.$ of the i.a.). The seeds were treated before sowing with carboxin + thiram $\left(60+60\right.$ g i.a. $100 \mathrm{~kg}^{-1}$ seeds) to prevent the appearance of possible diseases, caused by soil pathogens. The sowing was mechanical, on June 13, 2006. The area was then spray irrigated by a central pivot with a water sheet of approximately 14 $\mathrm{mm}$ to minimize $\mathrm{N}$ losses through ammonia volatilization and to promote seed germination.

Based on the chemical characteristics of the soil of the experimental area, the basic chemical fertilization was calculated in the sowing, constant for all the treatments, which was $10 \mathrm{~kg} \mathrm{ha}^{-1} \mathrm{~N}$ (urea), $70 \mathrm{~kg}$ ha $^{-1} \mathrm{P}_{2} \mathrm{O}_{5}$ (simple superphosphate) and $30 \mathrm{~kg} \mathrm{ha}^{-1} \mathrm{~K}_{2} \mathrm{O}$ (potassium chloride), in both growing seasons. The nitrogen fertilization was managed at $5 \mathrm{~cm}$ from the side of the furrow on the same day of sowing and the side dressing fertilization was between the plot rows, without incorporation to the soil, 40 days after plant emergence, when the plants were at the booting stage of the crop. After this fertilization, the area was spray irrigated with a water sheet of approximately $14 \mathrm{~mm}$ to prevent $\mathrm{N}$ losses through ammonia volatilization, that occurs because of urea hydrolysis. This operation is common in the irrigated grain production systems when urea is applied.

Water was supplied every three days or when necessary by spraying using a fixed irrigation system with a central pivot. The weeds were managed by applying metsulfuron methyl ( $3.0 \mathrm{~g} \mathrm{ha}^{-1}$ doi.a.) post emergence. The wheat was harvested by hand and individually per experimental unit, 105 days after plant emergence, respectively, when $90 \%$ of the ears presented grains with coloring typical of ripeness. The harvested material was dried in full sunshine and then threshed. The material was cleaned by hand.

The following assessments were made: a) number of spikelets per ear, and $b$ ) total number of grains per ear, for these determinations, 10 wheat ears were collected per experimental unit at harvest; c) plant height at maturity, defined as the distance $(\mathrm{cm})$ from soil level to the tips of the ears; d) leaf nitrogen content, analyzed on the flag leaf, collected when the crop began flowering (CANTARELLA et al., 1997); e) number of ears per meter at harvest and calculation of the number of spikelets per square meter; f) hectoliter matter, corresponding to the grain matter occupied in a $100 \mathrm{~L}$ volume determined on $1 / 4$ scales with grain water content corrected to $13 \%$ (wet base); g) mass of 100 grains, determined on $0.01 \mathrm{~g}$ precision scales, with the grain water content corrected to $13 \%$ (wet base); h) grain yield, determined by collecting plants from the three central rows of each plot. After mechanical threshing, the grains were quantified and the data transformed into $\mathrm{kg} \mathrm{ha}^{-1}$ at $13 \%$ (wet base).

The data was submitted to analysis of variance and the means compared by the Tukey test at $5 \%$ probability for the effect of nitrogen sources, nitrogen application period and cultivar, and fitted to regression equations for the effect of the nitrogen doses. The SISVAR statistical analysis program was used for the statistical analysis. Correlation analyses were performed for grain yield versus all the production components, individually.

\section{RESULTS AND DISCUSSION}

The 'E 22' wheat cultivar was statistically superior to the ' $\mathrm{E} 42$ ' cultivar, in the spikelets per ear and plant height and was $30 \mathrm{~cm}$ taller on average. On the other hand, the ' $\mathrm{E} 42$ ' cultivar produced higher numbers of grains per ear (Table 1). According to AUDE et al. (1994), in wheat, the number of flowers per spikelet and spikelets per ear depends on nutritional and environmental factors in addition to the factors inherent to the cultivar itself. No significant difference was detected among the $\mathrm{N}$ sources for any of the ear assessments (Table 1). However, Entec ${ }^{\circledR}$ promoted greater plant height than ammonium sulfate and urea. YANO et al. (2005) did not report significant difference among the nitrogen sources (urea, ammonium sulfate and ammonium nitrate) for wheat plant height.

There was no significant difference between the nitrogen application times for the number of spikelets per ear, grains per ear and wheat plant height. The $\mathrm{N}$ concentrations did not significantly influence any of these assessments either (Table 1), probably because there were high temperatures (the average and maximum temperatures were equal to $23.3^{\circ} \mathrm{C}$ and $30.1^{\circ} \mathrm{C}$, respectively) and low average relative humidity during ear formation and flowering, that impeded the effect of increase in the nitrogen doses on the number of spikelets per ear and grains per ear of these wheat cultivars. This indicated that these assessments depended on the genetic potential of the cultivar which was not 
Table 1 - Means, Tukey test and coefficients of variation for the number of spikelets per ear, number of grains per ear, plant height, leaf nitrogen content, number of ears per square meter, hectolitric mass, mass of 100 seeds and grain yield of two irrigated wheat cultivars influenced by sources, application times and doses of nitrogen. Selviria, MS, 2006.

\begin{tabular}{|c|c|c|c|c|c|c|c|c|}
\hline & $\begin{array}{l}\text { Number of } \\
\text { spikelets } \\
\text { per ear }\end{array}$ & $\begin{array}{c}\text { Number of } \\
\text { grains per } \\
\text { ear }\end{array}$ & $\begin{array}{l}\text { Plant height } \\
\qquad(\mathrm{cm})\end{array}$ & $\begin{array}{l}\text { Leaf } N \\
\text { content } \\
\left(\mathrm{g} \mathrm{kg}^{-1}\right)\end{array}$ & $\begin{array}{l}\text { Number of } \\
\text { ears per } \mathrm{m}^{2}\end{array}$ & $\begin{array}{c}\text { Hectolit. } \\
\text { Mass } \\
\left(\operatorname{kg~} 100 L^{-1}\right)\end{array}$ & $\begin{array}{l}\text { Mass of } \\
100 \text { seeds } \\
(\mathrm{g})\end{array}$ & $\begin{array}{l}\text { Grain yield } \\
\left(\mathrm{kg} \mathrm{ha}^{-1}\right)\end{array}$ \\
\hline \multicolumn{9}{|l|}{ Cultivars } \\
\hline E 22 & $17.47 \mathrm{a}$ & $37.79 \mathrm{~b}$ & $81.46 \mathrm{a}$ & $44.61 \mathrm{a}$ & 299 a & $83.51 \mathrm{a}$ & $3.68 \mathrm{a}$ & $3429 \mathrm{a}$ \\
\hline E 42 & $16.83 \mathrm{~b}$ & $44.43 \mathrm{a}$ & $68.29 \mathrm{~b}$ & $43.34 \mathrm{a}$ & $264 \mathrm{~b}$ & $81.14 \mathrm{~b}$ & $3.71 \mathrm{a}$ & 3422 a \\
\hline D.M.S. (5\%) & 0.32 & 1.10 & 0.74 & 0.81 & 11 & 0.72 & 0.08 & 111 \\
\hline \multicolumn{9}{|l|}{ Nitrogen Sources } \\
\hline Entec $(\circledR$ & $17.31 \mathrm{a}$ & $41.64 \mathrm{a}$ & $78.18 \mathrm{a}$ & $43.89 \mathrm{a}$ & $257 \mathrm{a}$ & 82.59 a & $3.22 \mathrm{~b}$ & $3440 \mathrm{a}$ \\
\hline Ammonium sulfate & $17.13 \mathrm{a}$ & $41.18 \mathrm{a}$ & $74.73 \mathrm{~b}$ & $44.21 \mathrm{a}$ & $266 \mathrm{a}$ & $82.52 \mathrm{a}$ & $3.64 \mathrm{a}$ & $3428 \mathrm{a}$ \\
\hline Urea & $17.01 \mathrm{a}$ & $40.52 \mathrm{a}$ & $75.20 \mathrm{~b}$ & $43.84 \mathrm{a}$ & $253 \mathrm{a}$ & $81.84 \mathrm{a}$ & $3.71 \mathrm{a}$ & 3409 a \\
\hline D.M.S. (5\%) & 0.46 & 1.60 & 1.08 & 1.19 & 16 & 1.05 & 0.12 & 163 \\
\hline \multicolumn{9}{|l|}{$\begin{array}{l}\text { Nitrogen application } \\
\text { times }\end{array}$} \\
\hline Sowing & $17.11 \mathrm{a}$ & $40.80 \mathrm{a}$ & $75.29 \mathrm{a}$ & $43.17 \mathrm{~b}$ & 258 a & 82.48 a & $3.72 \mathrm{a}$ & 3457 a \\
\hline Side dressing & $17.19 \mathrm{a}$ & $41.43 \mathrm{a}$ & $74.45 \mathrm{a}$ & $44.78 \mathrm{a}$ & 259 a & $82.15 \mathrm{a}$ & $3.67 \mathrm{a}$ & 3394 a \\
\hline D.M.S. (5\%) & 0.32 & 1.10 & 0.74 & 0.81 & 11 & 0.72 & 0.08 & 111 \\
\hline \multicolumn{9}{|c|}{ Nitrogen Doses $\left(\mathrm{kg} \mathrm{ha}^{-1}\right)$} \\
\hline 0 & 17.61 & 42.27 & 75.13 & 41.35 & 258 & 82.90 & 3.78 & 2854 \\
\hline 50 & 16.82 & 40.83 & 74.89 & 43.71 & 255 & 83.63 & 3.63 & 3435 \\
\hline 100 & 17.00 & 40.83 & 72.19 & 44.80 & 248 & 82.42 & 3.70 & 3657 \\
\hline 150 & 17.51 & 41.83 & 75.75 & 45.12 & 265 & 81.84 & 3.69 & 3591 \\
\hline 200 & 16.81 & 39.80 & 74.38 & 44.91 & 268 & 82.48 & 3.65 & 3401 \\
\hline Overall means & 17.15 & 41.11 & 74.88 & 43.98 & 282 & 82.33 & 3.70 & 3426 \\
\hline $\mathrm{CV}(\%)$ & 9.19 & 13.57 & 4.99 & 6.93 & 19.59 & 4.17 & 10.41 & 15.18 \\
\hline
\end{tabular}

Means followed by the same letter, in the column, do not differ by the Tukey test at the level of $5 \%$ probability.

limited by the nitrogen (FREITAS et al., 1995), but it was affected by the adverse climatic conditions in 2006. For CAMPOS et al. (2004), the occurrence of climatic adversities or disease and pests can be interpreted as disturbances to the transformation of the nutrients in harvested products.

The effect of applying $\mathrm{N}$ doses on the number of spikelets per ear and grains per ear of wheat reported in the literature varies greatly. BREDEMIER $\&$ MUNDSTOCK (2001) reported increase in the number of spikelets and the number of grains per ear and COELHO et al. (1998) obtained increase in the number of grains per ear of the 'E 22' wheat cultivar, both with the application of nitrogen doses. On the other hand, TEIXEIRA FILHO et al. (2008) did not find any effect of the nitrogen doses in two irrigated wheat cultivars.

Regarding plant height, there was no significant effect for the $\mathrm{N}$ doses and lodging was not observed in the plants in the experiment, even at the higher $\mathrm{N}$ doses. TEIXEIRA FILHO et al. (2008) did not observe plant lodging and significant effect of $\mathrm{N}$ dose application as side dressing in two irrigated wheat cultivars in the Cerrado region. However, ZAGONEL et al. (2002) observed that plant height increased as a function of $\mathrm{N}$ dose, at side dressing.

Table 1 shows that there was no significant difference between the 'E 22' and ' $\mathrm{E} 42$ ' wheat cultivars for the leaf $\mathrm{N}$ content. However, the high leaf nitrogen contents found in these cultivars is emphasized, contents well above the normal range (20 to $34 \mathrm{~g} \mathrm{~N} \mathrm{~kg}^{-1}$ dry matter) reported by CANTARELLA et al. (1997). Regarding the nitrogen sources, it was observed that Entec $^{\circledR}$, ammonium sulfate and urea resulted in similar leaf nitrogen contents. MEGDA et al. (2009) did not observe difference among the same $\mathrm{N}$ sources for the leaf $\mathrm{N}$ content of irrigated wheat in the Cerrado. It was observed for the nitrogen application times that applying nitrogen as side dressing resulted in a greater leaf $\mathrm{N}$ content than applying nitrogen at sowing (Table 1). This occurred because nitrogen as side dressing was applied closer to the flowering of the crop, period in which the flag leaf was collected to analyze the leaf nitrogen content. MEGDA et al. (2009) also stated that nitrogen application as side dressing resulted in greater $\mathrm{N}$ content in the wheat leaf when compared to applying nitrogen totally at sowing. The $\mathrm{N}$ doses only influenced 
the leaf nitrogen content of the 'E 22' cultivar and the data fitted the increasing linear function (Figure 1a). This increase in the $\mathrm{N}$ concentration of the wheat flag leaf, as a function of the increase in the $\mathrm{N}$ doses, was also reported by TEIXEIRA FILHO et al. (2007), but the response was quadratic and up to the dose of $77 \mathrm{~kg} \mathrm{ha}^{-1} \mathrm{~N}$.
The number of ears per $\mathrm{m}^{2}$ of the ' $\mathrm{E} 22$ ' cultivar was significantly greater than that observed for the 'E42' cultivar (Table 1). For SANGOI et al. (2007) under high densities, the number of ears $\mathrm{m}^{-2}$ is the most important production component. Entec ${ }^{\circledR}$, ammonium sulfate and urea didn't differ significantly for the

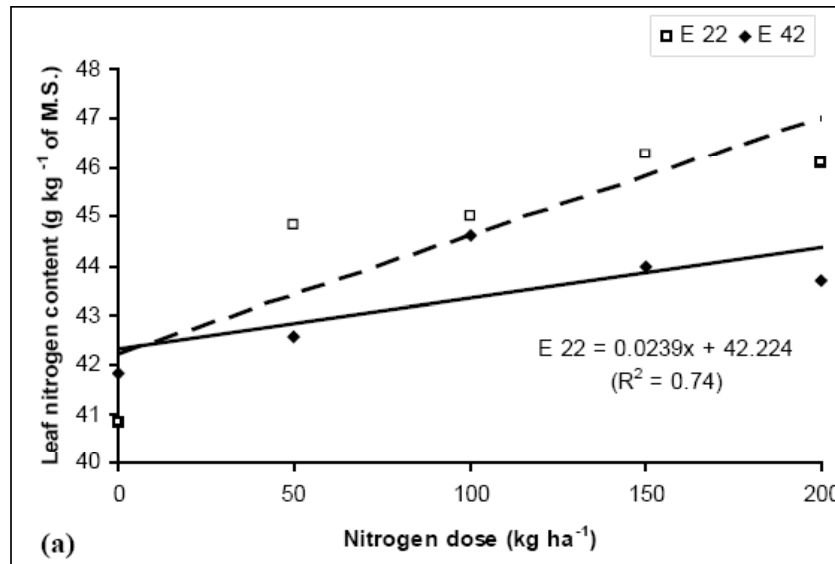

(a)

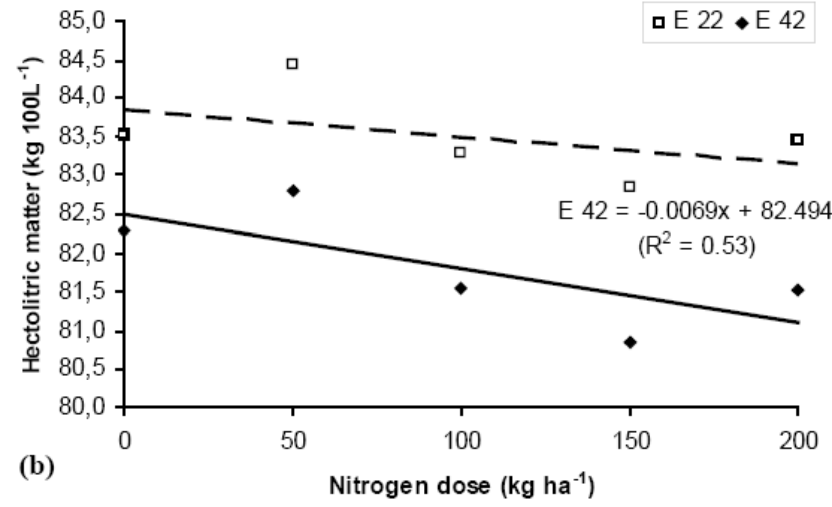

a $22 \bullet \mathrm{E} 42$

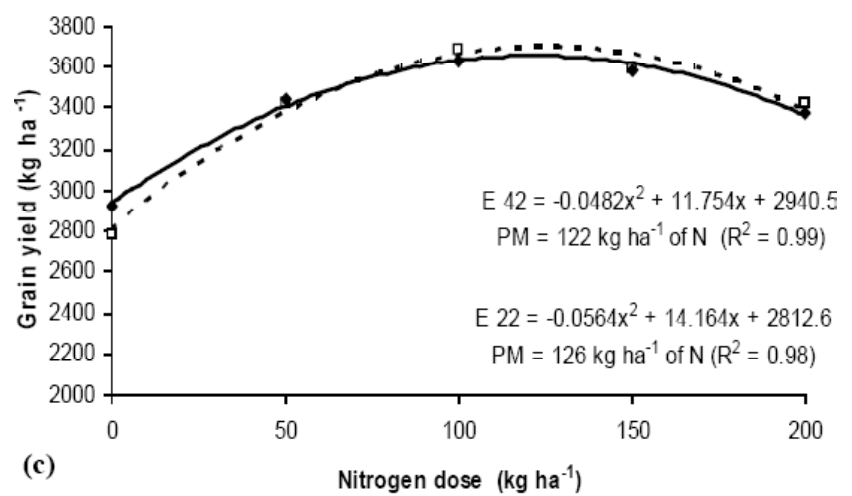

Figure 1 - Effect of the interaction nitrogen dose within cultivar of the analysis of variance for the (a) leaf nitrogen $\left(\mathrm{g} \mathrm{kg}^{-1}\right)$ content,

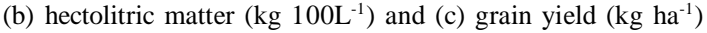
in wheat. Selviria, MS, 2006. 
number of ears per $\mathrm{m}^{2}$. The $\mathrm{N}$ application times did not differ significantly for this assessment either. There was also no influence of the nitrogen doses on the number of ear per $\mathrm{m}^{2}$. However, ZAGONEL et al. (2002) and TEIXEIRA FILHO et al. (2007) reported significant effect of the increase in the $\mathrm{N}$ doses applied as side dressing in the form of urea on the number of wheat ears per meter.

The hectolitric mass of the 'E 22' cultivar was significantly greater compared to the hectolitric mass of the ' $\mathrm{E} 42$ ' cultivar (Table 1). The nitrogen sources did not differ significantly for this assessment. Applying nitrogen totally at sowing also did not differ significantly from applying side dressing for hectolitric mass. However, it is pointed out that the high hectolitric

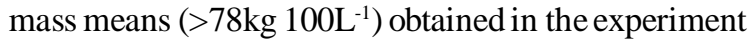
classified (analyzing separately) the wheat as type 1. In figure $1 b$, it can be stated that there was decreasing linear performance for hectolitric mass in the ' $\mathrm{E} 42$ ' cultivar as a function of the increase in the $\mathrm{N}$ doses. However, the 'E 22' cultivar was not influenced by the $\mathrm{N}$ doses (Figure 1b). TRINDADE et al. (2006) tested urea doses and also observed decreasing hectolitric mass values, as the nitrogen dose increased from 0 to $200 \mathrm{~kg} \mathrm{ha}^{-1}$.

Regarding the mass of 100 seeds (Table 1) there was no significant difference for the wheat cultivars. However, the $\mathrm{N}$ sources influenced this production component, and urea and ammonium sulfate resulted in greater mass of 100 seeds than $\mathrm{Entec}^{\circledR}$. The nitrogen application times did not differ statistically for this assessment. The $\mathrm{N}$ doses did not influence the mass of 100 seeds (Table 1). The increase in the nitrogen doses probably did not increase or reduce the mass of 100 seeds values because the number of grains per ear was not influenced by the $\mathrm{N}$ doses either, therefore, there was no competition for nutrients and photoassimilates within the ear and as a consequence, the unitary mass of the grains was not affected. The responses of the mass of 100 or 1000 grains to nitrogen fertilization reported in the literature vary greatly. ZAGONEL et al. (2002) also observed that nitrogen fertilization did not influence mass of 1000 grains. COELHO et al. (1998) reported increase in the mass of 1000 seeds up to 30 and $37.2 \mathrm{~kg} \mathrm{ha}^{-1} \mathrm{~N}$, with decrease in this component with higher $\mathrm{N}$ doses. TEIXEIRA FILHO et al. (2007) obtained increase in the mass of 100 seeds up to $68 \mathrm{~kg} \mathrm{ha}^{-1} \mathrm{~N}$, applied at side dressing in the form of urea.

The 'E 22' and 'E 42' cultivars did not differ significantly for grain yield (Table 1) and nor was there significant difference among the $\mathrm{N}$ sources for grain yield in this crop. This absence of response of the nitrogen sources probably occurred because the experiment was irrigated shortly after their application, thus reducing losses by volatilization, especially of the $\mathrm{NH}_{3}$ from urea. The $\mathrm{N}$ sources also performed similarly due to the low rainfall recorded in the cropping period, because the experiment was conducted in the dry season. Several authors compared various nitrogen fertilizers and in general, if there were satisfactory soil moisture conditions, differences were not detected in the efficiencies of these sources; as in wheat grain yield for the $\mathrm{N}$ sources: ammonium sulfonitrate ammonium sulfate and urea (MEGDA et al., 2009) and between urea and $\operatorname{Entec}^{\circledast}$ in the no till system (SILVA et al., 2008).

Regarding the nitrogen application period (Table 1), it was observed that anticipating nitrogenized fertilization did not differ significantly from applying $\mathrm{N}$ as side dressing for grain yield. This probably occurred because the soil where the experiment was carried was fairly fertile and well drained with clay and had good organic matter content. Furthermore, the wheat was cropped in a dry period with little rain, therefore the practice of early nutrient application was efficacious. ROS et al. (2003) tested different nitrogen fertilization methods in no till and assessed the $\mathrm{N}$ availability and also reported that total nitrogen application at sowing or as side dressing did not result in differences in wheat grain yield. Similarly, SILVAet al. (2008) did not observe significant difference between total nitrogen application at sowing and the traditional application in side dressing for wheat grain yield. However, when $\mathrm{N}$ was applied at pre-sowing and the precipitation exceeded the normal levels, grain yields and $\mathrm{N}$ uptake were significantly lower (BASSO \& CERETTA, 2000). This fact is possibly due to $\mathrm{N}$ leaching losses between the time of fertilizers application and the time of effective nutrient uptake by plants (DIECKOW et al., 2006).

The $\mathrm{N}$ doses influenced grain yield of the ' $\mathrm{E}$ 22 ' and ' $\mathrm{E} 42$ ' wheat cultivars (Figure 1c), fitted to quadratic functions, with maximum yield being reached, respectively, with the estimate of 126 and $122 \mathrm{~kg} \mathrm{ha}^{-1} \mathrm{~N}$. BREDEMEIER \& MUNDSTOCK (2001), ZAGONEL et al. (2002), TRINDADE et al. (2006) and TEIXEIRA FILHO et al. $(2007,2008)$ also reported the effect of N on crop yield. On the other hand, POTTKER et al. (1984) in function of the adverse climatic conditions (heavy rainfall alternated with periods of drought) did not observe the effect of $\mathrm{N}$ application on crop yield. This shows that the efficiency of the nitrogen applied depends on the condition studied such as cultivar, climate and management.

In the experiment, there was positive correlation between grain yield and leaf nitrogen 
content $\left(0.66^{* *}\right)$ of the 'E 22 ' cultivar. This showed the importance of the nutrient in the nutritional state of the wheat plant. It is also pointed out that the yields obtained in this low altitude tropical region were of the order of $3,426 \mathrm{~kg} \mathrm{ha}^{-1}$ (Table 1), thus showing that irrigated wheat is a feasible alternative in winter crop rotation in the Cerrado.

\section{CONCLUSION}

The efficiency of the ammonium sulfonitrate with nitrification inhibitor was not better than the ammonium sulfate and urea for most of the production components and for grain yield. Nitrogen application totally at sowing is feasible, as well as is the traditional application at sowing and in side dressing, for the wheat cultivars irrigated under no till, cropped in a region of low altitude Cerrado. The nitrogen doses increased the grain yield in the 'E 22' and 'E 42' wheat cultivars, respectively, up to doses of 126 and $122 \mathrm{~kg} \mathrm{ha}^{-1} \mathrm{~N}$, regardless of the application time and the nitrogen source.

\section{ACKNOWLEDGEMENTS}

To Coordenação de Aperfeiçoamento de Pessoal de Nível Superior (CAPES) and to the Conselho Nacional de Desenvolvimento Científico e Tecnológico ( $\mathrm{CNPq})$, for scholarships; and the Fundação de Amparo à Pesquisa do Estado de São Paulo (FAPESP), for financial support.

\section{REFERENCES}

AUDE, M.I.S. et al. Taxa de acúmulo de matéria seca e duração do período de enchimento de grão do trigo. Pesquisa Agropecuária Brasileira, v.29, n.10, p.1533-1539, 1994.

BASSO, C.J.; CERETTA, C.A. Manejo do nitrogênio no milho em sucessão a plantas de cobertura de solo, sob plantio direto. Revista Brasileira de Ciência do Solo, v.34, n.4, p.905915, 2000

BREDEMEIER, C.; MUNDSTOCK, C.M. Estádios fenológicos do trigo para a adubação nitrogenada em cobertura. Revista Brasileira de Ciência do Solo, v.25, n.2, p.317-323, 2001.

CAMPOS, L.A.C. et al. Informações técnicas das comissões centro-sul brasileira de pesquisa de trigo e triticale para a safra 2004. Londrina: IAPAR/EMBRAPA, 2004. 214p.

CANTARELLA, H. et al. Cereais. In: RAIJ, B. Van, et al. Recomendações de calagem e adubação para o Estado de São Paulo. Campinas: IAC, 1997. 285p. (Boletim técnico, $100)$.

COELHO, M.A.O. et al. Resposta da produtividade de grãos e outras características agronômicas do trigo EMBRAPA-22 irrigado ao nitrogênio em cobertura. Revista Brasileira de Ciência do Solo, v.22, n.3, p.555-561, 1998.
DIECKOW, J. et al. Nitrogen application timing and soil inorganic nitrogen dynamics under no-till oat/maize sequential cropping. Revista Brasileira de Ciência do Solo, v.30, n.4, p.707-714, 2006. Available from: <http://www.scielo.br/ s cie lo.php? s c ri pt $=\mathrm{sci}_{-}$art text \& pid = S $0100-$ 06832006000400011>. Accessed: Jan. 30, 2011. doi: 10.1590/ S0100-06832006000400011.

EMPRESA BRASILEIRA DE PESQUISA AGROPECUÁRIA. Sistema brasileiro de classificação de solos. 2.ed. Rio de Janeiro: EMBRAPA/CNPSo, 2006. 306p.

ERNANI, P.R. Disponibilidade de nitrogênio e adubação nitrogenada para macieira. Lages: Graphel, 2003. 76p.

FREITAS, J.G. et al. Eficiência e resposta de genótipos de trigo ao nitrogênio. Revista Brasileira de Ciência do Solo, v.19, n.3, p.229-234, 1995.

KLUTHCOUSKI J. et al. Manejo antecipado do nitrogênio nas principais culturas anuais. Informações Agronômicas, n.113, 24p, 2006. (Informações Agronômicas, 113). Available from: <http://www.infoteca.cnptia.embrapa.br/bitstream/doc/214909/ 1/doc188.pdf $>$. Accessed: Jan. 23, 2008.

LOS FERTILIZANTES y su uso. 4.ed. Roma: FAO/IFA, 2002, p.87. Disponível em: 〈www.fertilizer.org>. Acesso em: 05 set. 2006 .

MEGDA, M.M. et al. Resposta de cultivares de trigo ao nitrogênio em relação às fontes e épocas de aplicação sob plantio direto e irrigação por aspersão. Ciência e Agrotecnologia, v.33, n.4, p.1055-1060, 2009. Available from: <http:// www.scielo.br/scielo.php?script $=$ sci_arttext $\&$ pid $=S 1413$ 70542009000400016>. Accessed: Nov. 25, 2009. doi: 10.1590/ S1413-70542009000400016.

POTTKER, D. et al. Doses e métodos de aplicação de nitrogênio para a cultura do trigo. Pesquisa Agropecuária Brasileira, v.19, n.10, p.1197-1201, 1984

RAIJ, B. Van; QUAGGIO, J.A. Métodos de análise de solo para fins de fertilidade. Campinas: IAC, 1983. p.11-31. (Boletim Técnico Instituto Agronômico, 81).

ROS, C.O. da, et al. Disponibilidade de nitrogênio e produtividade de milho e trigo com diferentes métodos de adubação nitrogenada no sistema plantio direto. Ciência Rural, v.33, n.5, p.799-804, 2003. Available from: <http://www.scielo.br/scielo.php?pid=S0103$84782003000500002 \&$ script $=$ sci_arttext\&tlng=es $>$. Accessed: Jan. 28, 2008. doi: 10.1590/S0103-84782003000500002.

SANGOI, L. et al. Características agronômicas de cultivares de trigo em resposta à época da adubação nitrogenada de cobertura. Ciência Rural, v.37, n.6, p.1564-1570, 2007. Available from: <http://www.scielo.br/pdf/cr/v37n6/a10v37n6.pdf>. Accessed: Jan. 27, 2008. doi: 10.1590/S0103-84782007000600010.

SILVA, S.A. da, et al. Fontes e épocas de aplicação de nitrogênio em trigo em sistema plantio direto no cerrado. Revista Brasileira de Ciência do Solo, v.32, n.spe, p.2717-2722, 2008. Available from: <http://www.scielo.br/ s c i e lo.ph p s c ri pt $=$ sci_art text \& pid=S $0100-$ 06832008000700015>. Accessed: Jan. 27, 2009. doi: 10.1590/ S0100-06832008000700015. 
TEIXEIRA FILHO, M.C.M. et al. Resposta de cultivares de trigo irrigado por aspersão ao nitrogênio em cobertura na região do Cerrado. Acta Scientiarum-Agronomy, v.29, n.3, p.421425, 2007. Available from: <http://periodicos.uem.br/ojs/ index.php/ActaSciAgron/article/view/471/283>. Accessed: Nov. 21, 2007. doi: 10.4025/actasciagron.v29i3.471.

TEIXEIRA FILHO, M.C.M.et al. Desempenho agronômico de cultivares de trigo em resposta a população de plantas e a adubação nitrogenada. Científica, v.36, n.2, p.97-106, 2008. Available from: <http://cientifica.org.br/index.php/cientifica/ article/view/248/137>. Accessed: Nov. 23, 2008.

TRINDADE, M.G. et al. Nitrogênio e água como fatores de produtividade do trigo no cerrado. Revista Brasileira de
Engenharia Agrícola e Ambiental, v.10, n.1, p.24-29, 2006. Available from: <http://www.scielo.br/pdf/rbeaa/v10n1/ v10n1a04.pdf>. Accessed: Jun. 15, 2007. doi: 10.1590/S141543662006000100004.

YANO, G.T. et al. Avaliação de fontes de nitrogênio e épocas de aplicação em cobertura para o cultivo do trigo. Semina, v.26, n.2, p.141-148, 2005. Available from: < http://www.uel.br/ revistas/uel/index.php/semagrarias/article/viewArticle/2281 >. Accessed: Jul. 15, 2007.

ZAGONEL, J. et al. Doses de nitrogênio e densidade de plantas com e sem um regulador de crescimento afetando o trigo, cultivar OR-1. Ciência Rural, v.32, n.1, p.25-29, 2002. Available from: <http://www.scielo.br/pdf/cr/v32n1/a05v32n1.pdf>. Accessed: Jun. 17, 2007. doi: 10.1590/S0103-84782002000100005. 